\section{Dragan Momirović ${ }^{1}$}

Faculty of Business Economics

and Entrepreneurship, Belgrade

Marko Janković ${ }^{2}$

Faculty of Business Economics

and Entrepreneurship, Belgrade

Maja Ranđelović ${ }^{3}$

JKP. ,Niš parking” Niš
SCIENTIFIC REVIEW ARTICLE

doi:10.5937/ekonomika1601083M

Received: January 16, 2016

Accepted: February 14, 2016

\title{
INVENSMENT, WORLD ECONOMY AND POOR COUNTRIES
}

\begin{abstract}
World income is unevenly distributed among developed and rich countries on the one side and the poor and less developed countries on the other side. Poor countries in an attempt to develop its economy faces multiple barriers, the most important population growth, deficiency of resources and capital, shortage of investment in human capital traditions, investment in infrastructure, a low productivity in agriculture and conflicts. Poor countries are trying to develop their economies exporting primary goods order to achieve the benefit of export revenue for the procurement of capital goods. However, fluctuations in the real prices of primary export goods on the world market that can range up from to $40 \%$, disabling poor countries to fully substitute the export of primary goods import capital equipment, especially when exports focused on one primary good. To avoid decreasing a trend in real prices and large price fluctuations around this trend, the poor countries, (primary producers) can only strengthen their economies and increase economic growth of the within global economy, pooling, in order to ensure the stabilization mechanism for certain primary good. Less developed countries consider that achieve greater developments before focusing on industry than on primary production. That is why those due to a shortage of capital, unfavorable resorting to borrowing. Many poor countries cannot require repayment of debt and the rescheduling. Therefore, it is economically justified to those its economic development based on unused comparative advantages, structural adjustment through increased investment, productivity and efficiency. Poor countries require help through international transfers, because they consider that many countries have enriched the colonial exploitation of their resources.
\end{abstract}

Key words: poor countries, capital, economic growth, debt reprogramming, aid JEL Clasifiticitation: F43,O12,E24

\footnotetext{
${ }^{1}$ draganmomirovic@ymail.com

${ }^{2}$ markojankovic@outlook.com

${ }^{3}$ maja.randjelovic3.5@gmail.com
} 


\title{
ИНВЕСТИЦИЈЕ, СВЕТСКА ПРИВРЕДА И СИРОМАШНЕ ЗЕМЉЕ
}

\begin{abstract}
Апстракт
Светски доходак се неједнако распоређује између развијених и богатих земаља с једне стране и сиромашних и мање развијених земаља с друге стране. Сиромашне земье у покушају развоја своје привреде наилазе на многобројне препреке од којих су најважније раст становништва, дефицитарност ресурса, недостатак капитала, недостатак инвестирања у људски капитал, отиције у инфраструктуру, ниско продуктивна пољопривреда и конфликти. Сиромашне земье покушавају да развију своје економије извозом примарних добара како би оствариле корист од извозних прихода за набавку капиталних добара. Међутим, колебљивост реалних ичена примарних извозних добара на светском тржишту, које се крећу и до 40\%, онемогућавају сиромашне земље да у потпуности супституишу извоз примарних добара увозом капиталне опреме, посебно када је извоз усредсређен на једно примарно добро. Да би избегле опадајући тренд реалних ичена и велике флуктације чена око тог тренда, сиромашне земье, (примарни произвођачи) једино могу да ојачају своје економије и повећају привредни раст, у оквиру светске привреде, удружсивањем, ради обезбеђењ а стабилизационог механизма за одређено примарно добро. Мање развијене земье сматрају да ће већи развој остварити усредсређивањем пре на индустрију него на примарну производюу. Због тога оне, услед недостатка капитала, прибегавају неповољном задуживању. Многе сиромашне земье, не могу да отплате дуг и траже репрограмирање. Због тога, економски је оправдано да оне свој привредни развој базирају на неискоришћене компаративне предности, структуралним прилагођавањем кроз повећање инвестиција, продуктивности и ефикасности. Сиромашне земье захтевају помоћ путем међународних трансфера, јер сматрају да су се многе земье обогатиле колонијалном експлоатацијом њихових ресурса.
\end{abstract}

Кључне речи: сиромашне земље, капитал, привредни развој, репрограмирање дуга, помоћ.

\section{Introduction}

The current world economy, placed through world trade and finance, adjusted to the needs of rich countries and international financial and corporate capital. In the function of these interest groups is the leading international institutions World Bank, International Monetary Fund and the World Trade Organization. These institutions apply economic policy on the world, adopted by the Washington consensus. This policy is exclusively focused on achieving the highest possible efficiency. Social and environmental consequences of this policy are ignored. Issues of social justice, unemployment, poverty and threats to the environment are left to the states and their organizations.

The implementation of global policies on the principles of the Washington Consensus endangered the many countries and leads them in a difficult economic 
and social situation. The focus on this policy to prevent inflation and savings has not brought the expected results. Advice poor and some transition countries have influenced the drastic decline in their production and living standards. This led to the lagging behind of economic development. Less developed countries is recommending the purpose of restrictive monetary and budgetary policies instead of anti-cyclical policy to encourage economic growth. Insisting on the budget balance and the decreases of public expenditure, even in a period of stagnation or recession, has had devastating consequences of economic development and social situation. The policy of high interest rates has exacerbated, already sensitive situation and affected the excessive growth of foreign debt of poor countries.

The consequences of such policies are even greater stratification of world society into rich and poor. World income is unevenly distributed among the developed and rich countries on the one side and the poor and less developed countries on the other. The new world economic consensus is deepened and widened the gap between rich and poor. From 1990 to 2011, the number of extremely poor has expanded on 217 million to 415 million people. Average life expectancy, the population on these environments, it is 56 years, illiteracy $41 \%$ and the daily wage is less than $\$ 1.25$.

The causes of poverty is the consequence of the rest of the inherited colonial of bondage, fragmentation of space on a small number of states, with arbitrary boundaries, which are chronic sources of tribal conflict, mostly around its rich natural resources, population growth, insufficient of natural resources, the deficiency of physical and human capital, low productivity, customs and lack of investment in infrastructure. Then, the exploitation of natural resources by foreign companies that did not interested to accumulate and finance economic development already achieved profits reinvested and guides to other parts of the world. Not unusual collaboration, foreign multinationals company, with corrupt political elites on common interests and against the interests of their own countries and population.

The poor and less developed countries are trying to develop their own patterns of economic growth, using natural comparative advantages and benefits from the world environment. Many of them have attempted, through international trade, exports to primary goods; provide enough financial resources for the procurement of capital goods. Fluctuations in prices of primary products, downward, to the world market are major obstacles to development through substitution of imports with exports. The problems of price fluctuations, less developed countries are trying to solve, by association, through building stabilization mechanism for certain primary good. But trying association for other primary goods failed. A number of manufacturers, their indebtedness, and circumvention of the agreement and the time constraints on the agreement are the major reasons for the failure.

Less developed countries are considered to be greater development to achieve the transition to industrialization using a comparative advantage than the substitution of imports by exports of primary goods and products. Countries that have implemented the advice of leading world institutions and strictly applied their rules have not achieved economic development and industrialization. Countries that are acted precisely contrary to, such as China, Hong Kong, Singapore and others, opening their economies and the leading role of the state have achieved an enviable economic growth and exit from poverty. 
Less developed countries, deficiency of capital, they resort to borrowing on the financial markets. Credit conditions were unfavorable. The increase in interest rates over $20 \%$, after the postings does not pay a debt of Argentina, eighties, foreign debts of less developed countries have increased enormous. Service the debt is difficult. It has drawn world attention to a serious approach to resolving debt problems.

Many less developed countries, they cannot pay off a debt. They are forced to seek debt rescheduling or write-off. Creditors under pressure on of their governments and international institutions, in part, often are written off the debts of heavily over indebted countries.

Less developed countries often receive help. But they make remarks that such aid be insufficient. They considered that the rich countries have enriched colonization, exploitation of their natural resources, inexpensive labor force and reinvested in their own country. Rich countries now need to give them that part from their compensation. They want their rich countries open their markets decrease or eliminate high protection measures and do not intentionally cause price fluctuations of their products.

\section{The distribution of income and welfare}

The world has a population of 7 billion people. Of this population, $80 \%$ live in developing countries, $15 \%$ in developed economies, and about $5 \%$ in countries in transition. Contrary to the territorial distribution of the population, distribution of product of the world is completely different. The richest $20 \%$ of the world population receives more than $60 \%$ of income in the world; the poorest $20 \%$ receive less than $2 \%$ and the poorest $60 \%$ receive less than $6 \%$ of world income. ( McConnell, 2012, p. 39W-2)

Table 3. Peer capita 2013 (GNI PPP per capita \$US)

\begin{tabular}{|l|c|c|c|c|}
\hline \multicolumn{1}{|c|}{ Group of countries } & Word & Developed country & $\begin{array}{c}\text { Middle-income } \\
\text { country }\end{array}$ & Least developed country \\
\hline Per capita $^{1}$ & 14.432 & 40.779 & 9.558 & 1.960 \\
\hline Life expectancy $^{1}$ & 71 & 79 & 70 & 62 \\
\hline${\text { Illiteracy }(2005-2014)^{2}}^{2}$ & 15 & $<0,5$ & 17 & 39 \\
\hline
\end{tabular}

Source1. The Little Data Book, Word Bank Group, 2015

Source 2. Calculated on the basis of data from Education for All 2000-2015, (2015) Achievements and Challenges, EFA Global Monitoring Report, UNESCO Publishing

GDP per capita, shows the unequal distribution of income in the world. In poor countries in 2014 lived $40 \%$ of the population which has achieved a $\$ 1,960$ per capita income. In rich countries, the average incomes per capita were $\$ 40,779$. The highest per capita were achieved in developed economies and the lowest in extremely poor countries. The difference is drastic which indicates level of welfare of the world.

\section{Economic growth}

In low-income countries, it is noticeable improvement in the situation since 1965. Gross domestic product recorded a higher growth rate than the growth rate of 
developed countries. Despite the evident increase in the GDP the gap between rich and poor countries is expanded even further.

Table 4. The growth gross domestic product

\begin{tabular}{|l|c|c|c|c|c|c|}
\hline Group of countries & $1965-2000$ & $2007-2010$ & 2011 & 2012 & 2013 & 2014 \\
\hline High-income countries & & 0,6 & 1,7 & 1,5 & 1,2 & 2,1 \\
\hline Upper-middle-income countries & 2,6 & 5,9 & 5,9 & 5,1 & 4,6 & 5,3 \\
\hline Lower-middle-income countries & 1,6 & 6,1 & 5,8 & 4,4 & 4,7 & 5,0 \\
\hline Low-income countries & 2,2 & 6,1 & 6,2 & 6,0 & 5,7 & 6,1 \\
\hline
\end{tabular}

Source: The Little Data Book, Word Bank Group, 2015

Increasing growth of less developed countries is the result of improving global and regional environment of relatively high commodity prices, reduced infrastructure limitations and increasing investment and trade cooperation with the emerging economies. (Word Economic Situation and Prospects 2014, p. 8) In 2013, there has been some of this slowing economic growth of a tendency towards improvement. Some improvement depends on changes in global demand, easing monetary policy and stabilization of international capital flows. The increase in private consumption, increase exports and structural adjustment in many economies middle of the poor and poorest countries influenced to an increase in growth rates.

\section{The development of the export of primary goods}

Many less developed countries through trade with primary products trying to get out of poverty. Trade brings benefits. It leads to specialization based on comparative advantages. Many less developed countries dispose the most land. Some have minerals and other goods. In less developed countries, it is best to take advantage of the global economy for their own development if exported primary goods that require relatively intensive land use.

Less developed countries, mostly imported non-durable (soft goods) to consumer goods, agricultural products, such as cocoa, coffee, cotton and sugar, and minerals (hard goods) such as copper, aluminum, etc. Underdeveloped countries are constantly trying to exploit its comparative advantages in soil and minerals and achieve economic growth. Through trade, they tend to export primary products on the world market, achieved enough income how can we to import the necessary fixed capital and other resources.

Low income countries have dramatically increased their participation in world trade of the last two decades, with its share in total world exports from $21 \%$ to $43 \%$ and export growth exceeded the growth of output in these economies in the period 19922008. (Hanson, 2012, p. 41-46). 
Table 6. Export goods and services (\% GDP)

\begin{tabular}{|l|c|c|c|}
\hline Group of countries & 1990 & 2000 & 2013 \\
\hline High-income countries & 19 & 25 & 30 \\
\hline Middle-income countries & 19 & 27 & 30 \\
\hline Low-income countries & 12 & 18 & 22 \\
\hline
\end{tabular}

Source: The Little Data Book, (2015) Word Bank Group,

\section{Prices of primary products}

Market of primary goods is unstable with large price oscillations. Fluctuations in price by $30 \%$ or more for a period of one year or more are not uncommon. These markets are unstable and dangerous for all exporters of primary goods. Especially uncertain expected export revenue. Export revenue depends on the export prices on the world market. Unstable export prices make it impossible the government to obtain the expected stable revenues for the execution of development programs in the areas of education, health and imports.

Table 7 World price primary goods 2008-2014

\begin{tabular}{|l|c|c|c|c|c|}
\hline \multirow{2}{*}{ Good name } & \multicolumn{4}{|c|}{ Word prices of primary goods2008-2014 } & \multirow{2}{*}{ 2012-2014 versus 2003-2008 } \\
\cline { 2 - 5 } & 2008 & 2010 & 2012 & 2014 & 38,8 \\
\hline Cocoa & 32,2 & 8,5 & $-19,7$ & 23,7 & 86,1 \\
\hline Sugar & 26,9 & 17,3 & $-17,1$ & $-1,8$ & 62,4 \\
\hline Rubber & 16,9 & 90,3 & $-30,5$ & $-21,8$ & $-11,3$ \\
\hline Aluminum & $-2,5$ & 30,5 & $-15,8$ & $-5,0$ & 163,7 \\
\hline Gold & 25,1 & 26,1 & 6,4 & $-8,5$ & \\
\hline
\end{tabular}

Source: Trade and Development Report, 2014, untcad

Prices of primary products, the less developed countries for decades have shown a decreasing trend except for crude oils and gold. The cartel OPEC holding crude oil supply under control and the price of gold is artificially controlled. The decrease in commodity prices indicates that a higher supply than demand in the world market. Less developed the countries that export to the developed countries depending on economic trends in these countries. The recession in developed countries leaves visible squares in the exporting country. The demand for primary and other export products is declining. The fall of demand for primary goods has as a consequence decrease of their prices. During the recession 2007-2009 world zinc prices decreased from \$ 2.02 to \$ 0.49 per kilogram and the price of copper from $\$ 4.05$ to $\$ 1.40$ per kilogram. The decrease of prices and the decrease of demand for zinc and copper have been severely affected the decrease in of export revenue in exporting countries. Technical and technological advances in the production of new materials, like rubber and plastics, have contributed to the decrease in prices of many traditional raw materials in industrial countries. The largest exporters of primary goods are less developed countries.

Trade performances of the less developed countries are closely related to the dynamics of prices on the world market. Therefore, the fluctuation of prices of primary 
goods the key issue for them. High fluctuations in prices of primary goods in the world market are a long-term phenomenon. In some primary, soft and hard goods, due to the perfect concentration of exports, prices are high fluctuations ranging between $30-50 \%$ on a monthly basis. Less developed countries have never been to clean when it comes to world prices of primary goods. Their export earnings depend on the price fluctuations. They are not always as safe as will achieve export earnings. This uncertainty hinders them in realistic planning of capital goods imports.

The protectionist agricultural policies imposed by developed countries are one of the causes of the decrease in prices of agricultural products. The World Trade Organization and the General Agreement on Tariffs and Trade excluded decrease in customs duties in agriculture. Whenever the less developed countries succeeded in increasing the supply of agricultural products of the world market, the surplus had to be exported and sold in countries with less developed markets. Additional services at considerably decrease market led to a decrease in prices of agricultural products. Greater access to agricultural products on the markets of rich countries would certainly have a different impact on prices. Therefore, less developed countries, with the right to complain when it comes to strict control and protection of exports to the developed and rich countries.

\section{Concentration of exports}

Concentration of exports expresses the degree to which the exporting country concentrated on a few products or small number of trading partners. (Export Dependence and Export Concentration, Towards Human Resilience: Sustaining MDG Progress in an Age of Economic Uncertainty, 2012, p. 24). Some less developed countries in the world market, exporting a small number or only one primary product. Developing countries and less developed; had, because of the narrow range of primary products, the tendency to increase the concentration of exports. Despite an increase in the share of GDP, less developed countries in world trade, their exports are increasingly concentrated on a narrow range as compared to developed countries. (Export Dependence and Export Concentration, Towards Human Resilience: Sustaining MDG Progress in an Age of Economic Uncertainty, 2012, p. 25)

Table 8. Concentration of exports and fluctuations in export earnings 2002-2008

\begin{tabular}{|l|c|c|c|c|}
\hline \multirow{2}{*}{ Level of development } & \multicolumn{2}{|c|}{ Export concentration } & \% concentration & $\begin{array}{c}\text { Relative deviation export } \\
\text { earnings }\end{array}$ \\
\cline { 2 - 5 } & 2002 & 2008 & & 26,4 \\
\hline Developed countries & 0,07 & 0,06 & $-11,6$ & 38,6 \\
\hline Developing countries & 0,11 & 0,14 & 26,7 & 52,6 \\
\hline Underdeveloped contrived & 0,31 & 0,54 & 71,2 & \\
\hline
\end{tabular}

Source: Export Dependence and Export Concentration, Towards Human Resilience: Sustaining MDG Progress in an Age OF Economic Uncertainty,2012

The data onto the table show the volatility of the relationship between the concentration of exports and export revenues. The concentration of exports is strongly associated with an increase in volatility in export earnings. A higher degree of export 
concentration leads to relatively large deviations from exports. Underdeveloped countries have the highest ratio of the concentration of exports (row 3 ) and the largest relative variation in exports. Research by UNCTAD, with a sample of 133 countries for the period 1996-2008 shows that increasing the concentration of exports by $1 \%$ leads to an increase of $0.5 \%$ in exports. Less developed countries that export a primary good had great development problems.

\section{Schemes stabilization mechanism in prices of primary goods}

Primary producers may, in the framework of world trade achieved to benefit. The best example is members of OPEC countries. They were organized through joint action and determine the agreement's oil supply. In this way, they maintained a stable level of oil prices on the world market, and do not allow larger fluctuations. Form of organization OPEC should set an example, other countries producers of primary products, in order to organize and undertake jointaction. However they have no political power and are often faced with large purchases of monopoly. Association for producers of primary products would certainly lead to a stabilization of the prices of their goods and the stability of sources of export revenue.

Fluctuating export revenues, according to the permanent income hypothesis, can encourage savings. Unstable export may not be harmful. When the world markets are saturated primary products, the excess can be redeemed in commodity reserves and thus decreases the bids price and maintain the desired level. When demand increases, supplies with reserves can be exported and fill in the missing quantities of the market. The cost of storage, a large number of small producers and the administrative difficulties are limiting factors agreement on joint action on the global market of primary products. There are times, in some poor countries, where export-oriented industries do not spill over to the domestic economy. This is the case of enclaves in poor countries.

They dispose of agricultural plantations, mines and minerals are owned by foreign companies. Foreign companies use latest capital goods in intensive exploitation. These industries employ little labor and achieved profits accumulate abroad. These enclaves are isolated from the domestic economy, especially in sub-Saharan Africa and those countries have no use for revenue. The governments of these economies could achieve fiscal links to these industries and that tax money to finance their economic development.

Less developed countries have tried to organize mechanisms for stabilization of prices of primary goods. Countries in Africa, in the interwar zone, with primary products such as tin, rubber and tea are organized stabilization mechanisms for these products. Producers these primary products of each country were relatively few in number and produced goods are almost all gone to exports. Export is determined quotas that have changed from time. The manufacturers of these primary products are able to keep prices at the same level.

Many international agreements on during the nineties have become unsustainable, and many have collapsed. Agreement on cocoa production, which began in 1972, disbanded in 1988, they are no longer able to finance inventories. It is similar with other international agreements, for example, sugar, wool, coffee, tin, etc. Besides, effort, less 
developed countries, in general, failed to organize the pattern of OPEC. The governments of these countries do not have several large oil fields, but they are forced to engage a large number of small producers of primary products. They are very difficult to organize. For example, why wheat producers cannot be organized in the United States?

\section{Industrialization}

Development through specialization of production of primary products based on the comparative advantages not achieved the expectations of the less developed countries. Therefore, they have focused on industrialization. The arguments about industrialization are that it will facilitate a faster technological progress, decrease unemployment, increase income, to ensure stable export prices and income, encourage greater and accelerationmultiplier effects and contribute to the balance of payments.

Table 9. The added value in the process of industrialization, the degree of industrialization and income groups

\begin{tabular}{|c|c|c|c|c|c|c|}
\hline \multirow{2}{*}{ Group of countries } & \multicolumn{3}{|c|}{$\begin{array}{l}\text { Add production value (base } 2005, \$ \\
\text { billions) }\end{array}$} & \multicolumn{3}{|c|}{ The share of the value produced $\%$} \\
\hline & 1992 & 2002 & 2012 & 1992 & 2002 & 2012 \\
\hline Word & 4,960 & 6,590 & 8,900 & 100 & 100 & 100 \\
\hline High income industrializing & 175 & 273 & 495 & 19 & 18 & 16 \\
\hline $\begin{array}{l}\text { Upper middle income } \\
\text { industrializing }\end{array}$ & 57 & 91 & 163 & 6 & 6 & 5 \\
\hline $\begin{array}{l}\text { Lower middle income } \\
\text { industrializing }\end{array}$ & 657 & 1,140 & 2,410 & 73 & 75 & 78 \\
\hline Low income industrializing & 15 & 21 & 41 & 2 & 1 & 1 \\
\hline
\end{tabular}

Source: Industrial Development Reports, Sustaining Employment Growth: The Role of Manufacturing and Structural Change, 2013, United Nations

The process of industrialization, less developed countries has been able to implement in two ways: industrialization through import substitution and industrialization which is oriented on exports.

Selection of industrialization through import substitution suppresses the principle of comparative advantage and decreases world trade. Import substitution is a replacement of imported goods to their domestic production of protection for the form of higher customs tariffs or import quotas. (Beg et. 2005, p. 617) Less developed countries have used very high rates of effective protection. Customs rates in some countries, such as India, Pakistan, Argentina and Nigeria ranged between 100 and 200 percent. High customs tariffs and quotas aimed to divert domestic resources, of primary products, which have had such a comparative advantage in industrial production for which they have a comparative disadvantage. High protection and subsidies have contributed to the excessive volume of capital-intensive technology in the industry.

Capital intensity is quickly exhausted the lack of investment funds, with which they are disposed of under-developed countries, and opened a small number of new jobs. Due to a small number of new jobs, the annual population increase and employment rates in the agriculture and service sectors. The unemployment problem is only exacerbated. 
Expectations of higher salaries in industrialized societies have encouraged migration from rural to urban, which led to explosive situations. The priority was to build new plants and buying new plants. Lack of funds of the purchase of necessary reproductive material and energy from abroad has led to the emergence of excess capacity.

\section{Borrowing to growth}

The traditional source of funds of financing higher exports than imports is borrowing on the world market. Terms of borrowing were always unfavorable. Less developed countries did not have sufficient sources of domestic financial capital for investment. Therefore, they were forced to borrow under unfavorable conditions. Borrowing, they are supplemented lack of domestic investment capital due to low savings.

Repayment of debts, under-developed countries, has reached large proportions. More funds go to developed countries, in the name of debt repayment, but what is the inflow of capital in the form of loans and aid to less developed countries. What a paradox. Instead of the rich to the poor, financial capital, because of the large external debt goes from the poor to the rich.

The reason for the appearance of long interest rates is low, in the seventies of the last century. As long as real interest rates negative debt does not cause major damage. Less developed countries have easily borrowed and in some ways were subsidized by their creditors. To the pays the debts enough to sacrificed real resources.

Underdeveloped countries are mainly borrowed in the hope of foreign loans to accelerate the economic development and export. Increasing economic growth and exports will enable repayment of foreign debts. However, in many cases, this scenario did not play. Many less developed countries after years of borrowing became even poorer. They have got into economic difficulties from which they can hardly go out without international assistance.

\section{Reprogramming or write off the debt}

Less developed countries that have fallen into economic difficulties repayment of foreign debts have three options; you do not pay the debt, to seek rescheduling and cancellation of debts.

Do not pay the debt, it means a refusal to creditors generally pays off the debt. This is perhaps the easiest way but not comprehensively. What is the price of it? Governments of creditor may militarily intervene but it is a rare case. In the past and it happened. The United States sent troops in 1904 to the Dominican Republic government to force the payment of debt, French and British troops were forced Egypt in 1876 to pay the debt. Today the foreign debt collects no military force. There repressive methods of collection for the same or similar effects, which lead to a greater or lesser loss of real sovereignty of debtor countries. Usually, debt collection measures are implemented pressures on international negotiations, embargo, confiscation of assets abroad, limiting capital flows and the like.

Debt reprogramming is commonly applied method of the relaxation of repayment of foreign debts. The creditors accept debt reprogramming. Reprogram changing debt 
repayment plans but does not change the current amount of debt that must be paid. If the economy is growing debt reprogramming is a good strategy to get out of debt bondage.

Write-off of debt is a measure that applies of certain specific cases. Most economists believe that debt cancelation should not be made conditional on specific pressure or blackmail. Iraq's Paris Club wrote off 30\% of debt in 2004 in the amount of 40 billion US $\$$ with the conditions to pursue the full privatization and liberalization of the economy. A similar requirement is laid, Serbia and Nigeria.

\section{The development of the structural adjustment}

The economic crisis of the year 2008, after decades of silence, launched a much public debate on development. How to maintain growth? How to create permanent jobs? How to generate revenues and achieve accumulation? How to eradicate poverty and prevent social polarization?

Economic growth, less developed countries can achieve the structural adjustment of its economy. In principle, structural adjustment is governed by the terms of the supply and demand for products that respond to each other. (Industrial Development Reports, Sustaining Employment Growth: The Role of Manufacturing and Structural Change, United Nations, 2013, p. 3)

Less developed countries do not make full use of its built large capacities. They are not poor because of this. They are poor because of their potential product of a very low level. To maximize the potential for the product they need investments in human and physical capital. But sometimes that is not enough. They were in control of spending in order to increase investment. But it did not produce the expected results. Investments were eventually dropped to zero the economy stagnated.

Increasing productivity, less developed countries, do not have to increase from an increase in human and physical capital. One can increase productivity through better utilization of existing capacity and more efficient use of available resources. Countries that have opened their economies, and involved in global processes, achieved greater success than countries that have implemented protectionist measures.

Countries that have adopted structural adjustment, particularly in transition economies, have achieved greater economic success than before. Countries that have committed to reforms and believe in own prospects easier to accept structural adjustment and have a vision improve his welfare.

\section{Help from advanced economies}

Some argue that the simplest and most efficient way to help developed economies, less developed countries, so as to reduce trade barriers. Even, and less developed countries consider that the contribution that rich countries can provide poor countries is just free access to their markets. Trades and not mercy. This would allow less developed countries to sell their products of trade barriers, achieve higher revenues. The requirements of these countries, for the elimination or mitigation of barriers to trade in primary goods and labor-intensive industrial products, such as clothing, footwear, and food industry are 
justified. For example, customs tariffs are higher for imports of chocolate than for cocoa. This is a group of products for which some countries have a comparative advantage.

Some economists recommend that advanced economies, provide assistance to the less developed countries accepting the seasonal or temporary workers in their countries to work. Temporary or permanent migration allows the departure of redundant workers from less developed countries. Through emigration, they raise capital and land per worker staying. Money transfers to their families in their home country, they would improve their incomes. Discourage the sale of military equipment and weapons to underdeveloped countries. By purchasing military means, the already low consumption is diverted from infrastructure and education and increase tensions.

Public aid and grants, and technical assistance can play a major role in ensuring miss savings and investments. Many less developed countries lack the infrastructure needed to attract domestic and foreign capital. Financing infrastructure, foreign aid, can motivate a better flow of private capital.

\section{Flows of private capital}

Private capitals advanced economies have significantly gone in less developed countries. The structure of investment and lending has changed. We no longer provide loans to governments but in the form of foreign direct investment. The main private investors and lenders are private companies and individuals. Direct investments contribute to development through the construction of new factories or the purchase of multinational companies or firms of the least developed countries. Many countries are seeking foreign direct investment. They see their chance to hire its workforce, to improve workers' wages and increase physical capital. The benefit of direct investment is new technologies, new knowledge and management skills. Unfortunately, the flow of private capital in the world is quite selective. The flow of private capital, after the economic crisis of 2007 has dropped significantly in the world. For example, in 2014, total external flows to Africa were estimated at USD 181 billion, 6\% lower in nominal terms than in 2013. (African Economic Outlook, 2015, p. iii)

\section{Conclusion}

Less developed countries that have not changed advice the world's leading institutions, have opened economy and harmonize with globalization, have achieved obvious results of fighting against poverty.

Their economies have achieved a certain degree of improvement in the quality of life and welfare. The especially, countries, Southeast Asia, China, India, Vietnam, Singapore, etc. countries, Southeast Asia, China, India, Vietnam, Singapore, etc.

Other less developed countries, in particular, the countries of South Asia and the countries south of the Sahara have become even poorer. Even extremely are poor's countries. Part of the population is not involved in world civilization. The situation is extremely alarming.

However, development opportunities, other less developed countries, except for areas south of the Sahara and East Asia, in terms of neo-liberal globalization are 
not hopeless. Some Southeast Asian countries, especially China took advantage of globalization to their advantage. These countries have opened certain areas to the free operation of markets. They have approved the free flow of goods, capital, labor and free enterprise. The state has directed regulated and controlled economic development. Country's national development strategy and the control of natural resources and protect the long-term potential for national and social interests. The aim at the growth was the increase DDP already increasing education, health care, living standards and improving the social situation. This is the path and experiential model of development of less developed countries to exit the poverty zone.

Viewpoint neoliberals that international trade benefits everyone seem a myth. Fluctuation of prices of primary export goods less developed countries, up to $40 \%$ annually in some cases, down, is the most obvious proof. On the other hand, highly subsidized agricultural products in developed countries, on the world market are cheaper and more competitive and stifle export of agricultural products of less developed countries. High import customs tariffs rich countries and other measures make it difficult to import agricultural products of less developed countries. Prices of agricultural products are falling, revenues are reduced, and the vicious cycle of poverty becomes a labyrinth. Decreased revenue from preventing imports is greater than the total aid to less develop countries receive.

The liberalization of foreign trade opened the gates, the export of cheap manufactured products of less developed countries. This led to a slowdown and the blockade of the process of industrialization.

Borrowing to growth is not much helping, regardless of some initial successes. Debts are due to market disruptions and rising interest rates reached high proportions. Their annual repayment is larger than the total inflow of foreign capital in the form of grants and loans. There was a contradictory situation. Instead of capital going from the rich to the poor, he goes in the opposite direction. Therefore, less developed countries increasingly emphasize insufficient assistance.

The rescheduling and cancelation of debts have not yielded the expected results. Less poor countries see their way out of poverty by opening the rich countries' markets for their products. The decrease of customs tariffs, fewer subsidies, and stable price mechanism is the demands of rich countries.

Economically justified to less developed countries open up their economies and economic development based on the unexploited comparative advantages, structural adjustment through increasing investments, productivity, efficiency and integration into global trade flows.

\section{Reference}

Annual Report 2014, World Trade Organization, Begg, D., (2005) Fischer, S., Dornbusch R., Economical Data status, Beograd

Colander, K., (2011) Economics, Microeconomics, and Macroeconomics, Mc Graw Hill Irwin

Education for All 2000-2015, (2015) Achievements and Challenges, EFA Global Monitoring Report, UNESCO Publishing 
Export Dependence and Export Concentration, Towards Human Resilience: Sustaining MDG Progress in an Age of Economic Uncertainty (2012), United Nations Development Programme

Global Monitoring Report 2014/15 (2015) Ending Poverty and Sharing Prosperity, World Bank Group and International Monetary Fund

Hanson, G., (2012) The risk of Middle Kingdoms: Emerging economics in global trade, Journal of Economic Perspectives, vol. 26, No.2, pp.41-64

Industrial Development Reports, Sustaining Employment Growth: The Role of Manufacturing and Structural Change, (2013), United Nations Industrial Development Organization

Maddison A., (2011) Historical Statistics for world economy: 1-2008 AD

McConnell, R.C., (2012) International Economics, Chapter 39W2, The Economic of Developing Counters, University of Nebraska

Mesarić, M., (2007) Kako promjeniti model globalizacije da ona služi dobrobit čovječanstva, Ekonomski pregled, 58 (5-6), str. 347-385

Momirovic, D. Cogoljevic, D. (2015) Makroekonomja, Visoka škola za poslovnu ekonomiju i preduzetništvo, Beograd

OECD (2014a), Global Outlook on Aid: Results of the 2014 DAC Survey on Donors' Forward Spending Plans and Prospects for Improving Aid Predictability, unclassified document OECD, Paris,

The Little Data Book, (2015) World Bank Group,

Todaro, M.P. (1994) Economic Development (5th Ed... New York, London)

Trade and Development Report (2014), UNTCD

World Economic Situation and Prospects 2014, (2014) United Nations publication, Sales No 14. II. C.

African Economic Outlook, 2015

Further reading

Ravvallion, M. Chen, S., (2012) Monitoring Inequality, Let,s Talk Development Blog, World Bank http://blogs.worldbank.org/

https://www.imf.org/external/pubs/.../(2011) International Capital Flows: Reliable or Fickle? April 2011, Chapter 4 